\title{
A new method for analysis of plasma carotenoids in poultry
}

[Novo método para dosagem de carotenóides plasmáticos em aves domésticas]

\author{
M. Teixeira ${ }^{1}$, C.H.A. Meleiro ${ }^{2}$ \\ ${ }^{1}$ Departamento de Ciências Agrárias e Ambientais - UESC \\ Rodovia Ilhéus-Itabuna Km 16 \\ 45662-000 - Ilhéus, BA \\ ${ }^{2}$ Instituto de Tecnologia - UFRRJ - Seropédica, RJ
}

\begin{abstract}
A study was carried out to evaluate a new quantitative analytical technique for determination of plasma carotenoids in poultry. Plasma carotenoides were extracted and measured from 30 blood samples of male Cobb broilers. The new technique was efficient in detecting plasma carotenoids of chickens and also showed advantages upon those techniques currently in use such as the form of presentation of results, use of a compatible solvent, and the scanning method for reading. The new technique did not increase the cost of the analysis.
\end{abstract}

Keywords: poultry, plasma carotenoid, new analytical technique

\section{RESUMO}

Avaliou-se uma nova técnica analítica quantitativa para mensuração do teor de carotenóides plasmáticos em aves domésticas. Para extração e dosagem dos carotenóides plasmático, foram utilizadas 30 amostras de sangue de frangos de corte Cobb. A técnica testada foi capaz de detectar carotenóides no plasma das aves de forma eficiente tendo ainda vantagens sobre as técnicas correntes tais como a forma de apresentação dos resultados, uso de solvente compativel e método de leitura por varredura. A nova técnica não aumentou o custo da análise.

Palavras-chave: frango de corte, carotenóide plasmático, nova técnica analítica

\section{INTRODUCTION}

Carotenoids are natural pigments exclusively synthesized by photosynthetic organisms (Goodman, 1984). They provide colors to most vegetables ranging from yellow to dark red. According to the classification of Furr and Clark (1997), all carotenoids are derivated from an isoprenoid structure $\mathrm{C}_{40}$. The basic linear and symmetrical skeleton, which can be cyclized at one or both ends, has lateral methyl groups separated by six $\mathrm{C}$ atoms in the center and five $\mathrm{C}$ atoms elsewhere. Cyclization and other modifications, such as hydrogenation, dehydrogenation, doublebond migration, chain shortening or extension, rearrangement, isomerization, introduction of oxygen functions, or combinations of these processes, result in a myriad of structures. A distinctive characteristic is an extensive conjugated double-bond system, which serves as the lightabsorbing chromophore responsible for the yellow, orange, or red color that these compounds impart to many foods. Hydrocarbon carotenoids (i.e., carotenoids made up of only carbon and hydrogen) are collectively called carotenes; those containing oxygen are termed xanthophylls (RodriguezAmaya, 1999).

Plasma is usually made up of a mixture of compounds. Their levels directly reflects the amount acquired in the diet. Thus, different concentrations are found according to the animal species and its meal. Bovines have mostly $\beta$ carotene; chickens, xanthophylls; men and amphibians, all carotenoids; whereas most mammalian have none (Ganguly et al., 1958).

Recebido em 22 de fevereiro de 2008

Aceito em 23 de setembro de 2008

E-mail: marcel.teixeira@uesc.br

Apoio: $\mathrm{CNPq}$ 
During many years, the study of carotenoids was entirely motivated by activity of the provitamin A and its importance to human health. However, in the past decades, the study of these pigments has changed and interest in the metabolic via has increased due to the properties involved with antioxidant action inside the cells. This has been considered important in the prevention of degenerative disorders such as cancers, cataract, and macular degeneration.

Carotenoids are very important to animal production regarding animal health, but pigmentation chiefly represents a commercial value of carotenoids in the poultry market. Laying poultry are exposed to a very high pressure for production in the modern systems causing low pigmentation in egg yolk and skin discoloration. In addition, it is known that pigmentation could be altered by some diseases which directly affect the absorption of nutrients in intestine (Marusich et al., 1972). For example, the discovery of the relationship between coccidiosis and levels of plasma carotenoids in poultry stimulated many researches in the field of carotenoids analysis with a perspective of understanding the whole mechanism. For both nutrition and pathology, the knowledge of the determination of carotenoids becomes valuable for the poultry industry (Ruff and Fuller, 1975; Matthews et al., 1997; Matthews and Southern, 2000; Fetterer et al., 2003).

The protocol for analysis of plasma carotenoids with organic solvents designed by Wilson (1956) became the basis for sampling carotenoids and since then the method has been incremented with many modifications. Despite many contributions received so far, the method of Wilson (1956) with many adaptations will contribute for the improvement of the technique for analysis of carotenoids at laboratory.

The purpose of this work was to present a new method for sampling plasma carotenoids in poultry.

\section{MATERIAL AND METHODS}

Thirty-eight male Cobb broiler chickens, 14-dayold, were allocated after hatching in battery cages. Chicks were housed under constant lightning, fed, and water ad libitum. Animals were fed commercial starter ration containing approximately $23 \mu \mathrm{g} / \mu \mathrm{l}$ carotenoids naturally occurring in yellow corn (Allen, 1987).
Blood collection was performed by intra-cardiac punction. Samples were placed in glass tope covered tubes tubes $(10 \mathrm{ml})$ with $15 \%$ EDTA and plasma was separated from erythrocytes by centrifugation at $500 \mathrm{x} \mathrm{g}$ for 10 minutes. Plasma samples were kept away from heat and light ($18^{\circ} \mathrm{C}$ ) until the analysis.

Determination of the major carotenoid was the first step of the dosage. It consisted on the identification of the carotenoid showing the highest concentration in the sample. Thus, knowing that yellow corn is the main constituent of the ration, its chromatographic profile was used as reference (Oliveira, 2006) and zeaxanthin was identified as the major carotenoid to be used for the expression of results.

Extraction was performed with addition of $0.5 \mathrm{ml}$ plasma plus $4.5 \mathrm{ml}$ acetone in a glass tube, which was centrifuged at $660 \mathrm{x}$ g for 10 minutes. Then, samples were partitioned to a compatible solvent with addition of $8 \mathrm{ml}$ petroleum ether and plasma was extract in acetone in the phase separation and gently washed with distilled water.

Drying process was used to remove water from samples with $\mathrm{Na}_{2} \mathrm{SO}_{4}$. Then, salt was slowly added to attract water molecules. This could be easily observed by watching the agglutination of the salt at the bottom of the tubes, meaning water molecules were all led. As a rule, as soon as salt agglutination was seen in the "soup", the addition of salt was ceased. A good recommendation was to cover the tubes to protect against light degradation. Samples were be kept in refrigerator $\left(2-4^{\circ} \mathrm{C}\right)$ for 15 minutes to complete the process.

Samples were adjusted to a $10 \mathrm{ml}$ volumetricballoon glass and were read by the scanning spectrophotometer from 500 to $190 \mathrm{~nm}$ wave length. Quantification was performed according to the absorbance of carotenoids (Rodriguez-Amaya (1999):

$X_{(\mu \mathrm{g})}=\frac{\text { Abs. } \cdot 10^{6}}{A_{1 \mathrm{~cm}^{1 \%} \cdot 100}} \rightarrow X_{(\mu \mathrm{g} / \mathrm{ml})}=\frac{X_{(\mu \mathrm{g})}}{\mathrm{V}}$, where

Abs $=$ absorption maxima

$\mathrm{V}=$ calibration volume $(10 \mathrm{ml})$

$\mathrm{v}=$ plasma volume $(\mathrm{ml})$

$\mathrm{A}_{1 \mathrm{~cm}}{ }^{1 \%}=2348$ (absorption coefficient: absorbance at a

given wavelength of a $1 \%$ solution

at the spectrophotometer cuvette with a $1-\mathrm{cm}$ light path regarding zeaxanthin) 
For statistical analysis (Sampaio, 2002), means and standard deviation were calculated using Microsoft Excel ${ }^{\circledR}$ and both variance and SNKtest were calculated using the software SISVAR 4.6 (Ferreira, 2000).

\section{RESULTS AND DISCUSSION}

Plasma carotenoids were successfully measured by the new method. Data from measurements are presented in Table 1.

Table 1. Levels of plasma carotenoids in 38 male Cobb broilers chickens blood samples

\begin{tabular}{cc}
\hline Sample & $\mathrm{X}_{(\mu \mathrm{g} / \mathrm{ml})^{*}}$ \\
\hline 1 & 2.819 \\
2 & 1.584 \\
3 & 6.090 \\
4 & 2.061 \\
5 & 6.158 \\
6 & 3.799 \\
7 & 4.080 \\
8 & 3.118 \\
9 & 4.787 \\
10 & 6.082 \\
11 & 3.526 \\
12 & 3.339 \\
13 & 3.382 \\
14 & 3.918 \\
15 & 2.768 \\
16 & 4.898 \\
17 & 3.910 \\
18 & 4.702 \\
19 & 1.593 \\
20 & 3.390 \\
21 & 2.777 \\
22 & 3.629 \\
23 & 1.269 \\
24 & 2.010 \\
25 & 1.303 \\
26 & 2.070 \\
27 & 8.842 \\
28 & 4.157 \\
29 & 2.888 \\
30 & 4.097 \\
31 & 5.273 \\
32 & 2.487 \\
33 & 4.191 \\
34 & 2.070 \\
35 & 2.598 \\
36 & 2.751 \\
37 & 4.003 \\
38 & 2.683 \\
Mean & 3.555 \\
\hline & \\
\hline &
\end{tabular}

* carotenoids expressed in zeaxanthin
Some points will be discussed in order to show the advantages of the new method. First, regarding the form of presentation of results, levels of plasma carotenoids were expressed in micrograms of zeaxanthin per milliliter of plasma $\left(\mathrm{X}_{\mu \mathrm{g} / \mathrm{ml}}\right)$. According to recent nomenclature in carotenoid research, this presentation is more correct than current presentations in animal science. Wilson (1956) presented data in absorbance as read by the spectrophotometer, but it does not indicates which plasma component was measured. Ruff et al. (1974) modified the method of Wilson (1956) and presented the results as Klett units, which still remains inconclusive.

Augustine and Ruff (1984) were more specific presenting levels of carotenoids in micrograms of xanthophylls per milliliter of plasma, but xanthophylls are a wide class of carotenoids and, for this reason, the determination of a major carotenoid is needed. Knowing the major carotenoid is essential for the quantification, since absorption maxima is different for each xanthophyll in a specific solvent. Although Allen (1987) presented results based on a standard lutein curve, this carotenoid does not represent the major in commercial poultry diets.

Changing the solvent medium (from partition to compatible) is also very important for measuring plasma carotenoids. First, the acetone "cut off", from 200 to $320 \mathrm{~nm}$, leads to a great interference in the values of carotenoids measured with scanning spectrophotometer, since both solvent and samples are absorbed in the visible spectrum. Also, according to Rodriguez-Amaya (1999), the highly unsaturated carotenoid is prone to isomerization and oxidation. Heat, light, acids, and adsorption on an active surface promote isomerization of trans carotenoids, their usual configuration, to the cis form. Oxidative degradation, the principal cause of extensive losses of carotenoids, depends on the availability of oxygen and is stimulated by light, enzymes, metals, and co-oxidation with lipid hydroperoxides. Thus, total loss of color and biologic activities are the final consequences. Since carotenoids are also subject to isomerization and oxidation during analysis, preventative measures must be taken to guarantee the reliability of the analytic results. Acetone is a potent solvent for extracting carotenoids from chicken plasma but it results in 
high degradation, whereas petroleum ether guarantees good stability of plasma carotenoids during few days if keep at $4-8^{\circ} \mathrm{C}$. In addition, sharing of equipments by laboratories enables since stocks of samples to be prepared and read within a week.

The scanning method used for reading the samples of carotenoids is another advantage. Different wave lengths have been reported in the analysis of carotenoids, mostly as a fix spectrum. Scanning is a better method for covering all spectrum of absorption of carotenoids. In fact, this method provides the measurement of a mixture of carotenoids (total carotenoids) in the samples, which allows reading and consequently quantification in the maximum wave lenght $\left(\lambda_{\max }\right)$.

Although the new method spands more time to complete the analysis, this could not be considered a problem since the practitioners easily overcome this difficulty after training. Comparatively, the new technique did not increase the cost of this analysis because petroleum ether is not an expensive solvent.

\section{REFERENCES}

ALLEN, P.C. Physiological responses of chicken gut tissue to coccidial infection: comparative effects of Eimeria acervulina and Eimeria mitis on mucosal mass, carotenoid content and brush border enzyme activity. Poult. Sci., v.66, p.1306$1315,1987$.

AUGUSTINE, P.; RUFF, M.D. Changes in carotenoid and vitamin a levels in young turkeys infected with Eimeria meleagridis or Eimeria adenoides. Avian Dis., v.27, p.963-971, 1983.

FERREIRA, D.F. Manual do sistema SISVAR para análises estatísticas. Lavras: UFLA, 2000. $63 \mathrm{p}$.

FETTERER, R.H.; AUGUSTINE, P.C.; ALLEN, P.C. et al. The effect of dietary betaine on intestinal and plasma levels of betaine in uninfected and coccidian-infected broiler chicks. Parasitol. Res., v.90, p.343-348, 2003.
FURR, H.C.; CLARK, R.M. Intestinal absorption and tissue distribution of carotenoids. J. Nutr. Biochem., v.8, p.

GANGULY, J.; KRISHNAMURTHY, S.; MAHADEVAN, S. The transport of carotenoids, vitamin $A$ and cholesterol across the intestines of rats and chickens. Biochem. J., v.71, p.756-62, 1958.

GOODMAN, D.S. Overview of current knowledge of metabolism of vitamin A and carotenoids. J. Nat. Cancer Inst., v.73, p.13751379, 1984.

MATTHEWS, J.O.; SOUTHERN, L.L. The effect of dietary betaine in Eimeria acervulinainfected chicks. Poult. Sci., v.79, p.60-65, 2000.

MATTHEWS, J.O.; WARD, T.L.; SOUTHERN, L.L. Interactive effects of betaine and monensin in uninfected and Eimeria acervulina-infected chicks. Poult. Sci., v.76, p.1014-1019, 1997.

MARUSICH, W.L.; SHILDKNECHT, E.; OGRINZ, E.F. et al. Effect of coccidiosis on pigmentation in broilers. Br. Poult. Sci., v.13, p.577-585, 1972.

OLIVEIRA, G.P.R. Avaliação do milho $e$ derivados do milho como fontes de luteina $e$ zeaxantina. 2006. 89f. Dissertação (Mestrado) Universidade Estadual de Campinas, Campinas, SP.

RODRIGUEZ-AMAYA, D.B. A guide to carotenoid analysis in foods. Washington, DC: ILSI, 1999. 64p.

RUFF, M.D.; REID, W.M.; JOHNSON, J.K. Lowered blood carotenoid levels in chickens infected with Coccidia. Poult. Sci., v.53, p.18011809, 1974.

SAMPAIO, I.B.M. Estatística aplicada à experimentação animal. 2.ed. Belo Horizonte: FEPMVZ, 2002. 265p.

WILSON, W.O. Identifying non-laying chicken hens. Poult. Sci., v.35, p.226-227, 1956. 